\title{
ANALISIS LEMBAR KERJA SISWA (LKS) BIOLOGI KARYA MGMP SMP DI KOTA SEMARANG YANG DIGUNAKAN SISWA KELAS VII SEMESTER GASAL $2010 / 2011$
}

\author{
Izzun Nadlah \\ SMP Negeri 40 Semarang
}

\begin{abstract}
Abtraksi:
Pengalaman belajar dapat diperoleh siswa melalui serangkaian kegiatan dengan mengeksplorasi lingkungan melalui interaktif aktif dengan teman, lingkungan, dan nara sumber lain. Salah satu penunjang sarana pembelajaran yang dapat dipergunakan untuk mengeksplorasi lingkungan sekitar adalah dengan Lembar Kerja Siswa (LKS). Peningkatan aktivitas siswa sulit inyterjadi dengan sendirinya oleh karena itu peran guru sangat diperlukan untuk dapat menciptakan situasi belajar yang penuh dengan aktivitas siswa salah satunya menggunakan LKSFrekuensi penggunaan LKS yang cukup tinggi dalam setiap pembelajaran harus diimbangi dengan kualitas LKS yang tinggi juga. Umumnya siswa SMP di Kota Semarang. Adapun penelitian ini menggunakanmetode observasi dengan mengumpulkan data untuk me untuk mendapatkan harga Deskriptif Prosentasendapatkan harga Deskriptif Prosentase (DP) pada kesesuaian isi LKS dengan KTSP dan jenjang soal mendapatkan indeks pengaktifan (IP)pada petunjul kegiatan, gambar, atau diagram dan soal-soal latihan. Anali-
\end{abstract}


sis data menunjukkan LKS 65\%, berarti kategori sedang, indeks pengaktifan siswa pada petunjuk kegiatan sebesar 0,03 yang tergolong rendah, karena berada pada rentang 0,40 - 1,50. IP pada gambar atau diagram 1,37 yang tergolong sedang, karena berada pada rentang 0,40 - 1,50. Indeks Pengaktifan pada soal-soal latihan 1,23 yang tergolong sedang, karena berada pada rentang 0,40 - 1,50. Soal ranah kognitif tidak proporsional, karena $\mathrm{C} 1$ lebih dominan yaitu 40,8\% Soal ranah psikomotorik P2 0,43\% dan P3 1,3\%, sedang jenjang yang lain tidak ditemukan. Soal ranah afektif tidak ditemukan hal ini dikarenakan sulitnya mengaplikasikan muatan afektif ke dalam bentuk soal. Hasil penelitian ini diharapkan dapat menjadi informasi konkrit.Bagi siswa dan guru agar lebih memperhatikan LKS yang digunakan. Demikian pulabagi pihak pengarang agar lebih memperhatikan aspek-aspek yang mendukung kualitas LKS seperti kesesuaian isi LKS dengan kurikulum, tingkat pengaktifan siswa dan jenjang soal-soal latihan baik kognitif, afektif maupun psikomotorik.

Kata kunci: Analisis, LKS, Kurikulum, Pengaktifan, Jenjang 


\section{PENDAHULUAN}

Biologi ilmu mengkaji fenomena alam, tidak cukup dengan membaca, menghafal, mengerjakan tes untuk mengukur penguasaan konsep siswa tetapi perlu didukung kegiatan kerja ilmiah, melakukan percobaan, pengamatan, menganalisis data, berdiskusi, memaparkan hasil pengamatan, sehingga mampu menerapkan ketratrampilan, sikap dan nilai ilmiah pada diri siswa Hararapanya siswa mampu mengkaitkan pengetahuan yang mereka miliki untuk memecahkan masalah sederhana yang terjadi di lingkungannya. Hal ini sesuai dengan salah satu tujuan pembe lajaran Ilmu Pengetahuan Alam di SMP/MTs, yaitu memberikan pengalaman kepada siswa dalam merencanakan dan melakukan kerja ilmiah untuk membentuk sikap ilmiah (Anonim 2006).

Pengalaman belajar dapat diperoleh siswa melalui serangkaian kegiatan dengan mengeks plorasi lingkungan melalui interaksi aktif dengan teman, lingkungan dan nara sumber lain. Salah satu penunjang sarana pembelajaran yang dapat digunakan untuk mengeksplorasi lingkungan adalah Lembar Kegiatan Siswa (LKS). Peningkatan aktivitas siswa sulit terjadi dengan sendirinya oleh karena itu peran guru sangat diperlukan untuk menciptakan situasi belajar yang penuh dengan aktivitas siswa salah satunya dengan menggunakan LKS. Menurut Darmojo dan kaligis (1991) LKS sebagai alat bantu meningkatkan aktivitas siswa dalam proses belajar mengajar. LKS sebagai alat bantu dapat digunakan untuk membantu tumbuhnya kreativitas siswa agar dapat menjawab suatu permasalahan, sehingga dalam kegiatan pembelajaran siswa akan aktif mencari dan menemukan sendiri jawaban permasalahan sedangkan guru hanya sebagai moti fator dan fasilitator.

LKS digunakan sebagai panduan dalam pelaksanaan praktikum dan sarana bagi siswa untuk berlatih mengerjakan soalsoal, juga sebagai alternatif pemberian tugas oleh gu ru. Berdsarkan observasi yang telah dilakukan di beberapa SMP di kota Semarang hampir semua siswa mempunyai LKS karena diwajibkan oleh guru. Mengingat pentingnya peran LKS dalam 
upaya mencapai tujuan pendidikan, maka banyak pihak yang bergerak untuk menyusun LKSbaik dari pihak guru ataupun pihak swasta. Di kota Semarang LKS biologi yang banyak digunakan adalah LKS bantuan MGMP kota Semarang dengan alasan: 1) LKS sesuai dengan KTSP, 2) dapat untuk membimbing siswa dalam menggali konsep, kerjasama dalam kelompok dan pengembangan ketrampilan, 3) mempermudah proses KBM, 4) banyak memuat kerja ilmiah (praktikum), 5) soalnya bervariasi, 6) bahasa, tampilan dan penyajian materi sesuai dengan kondisi lingkungn dan kemampuan siswa di kota Semarang, 6) dilengkapi dengan ringkasan materi. Untuk mengetahui mutu dari LKS maka perlu dianalisis.

Beberapa aspek yang akan dianalisis meliputi kesesuaian LKS dengan KTSP, pengaktifan berdasarkan indeks pengaktifan siswa pada isi LKS dan persentase jenjang soal-soalnya. LKS yang berkualitas harus memenuhi aspek-aspek tersebut. LKS harus sesuai dengan kurikulum KTSP, sehingga berperan untuk mengaktifkan siswa. Pengukuran kopetensi siswa dapat memenuhi ranah kognitif, ranah psikomotor dan ranah afektif sehingga perlu diketahui persentase tiap jenjang soal-soalnya. Berdasarkan uraian tersebut maka rumusan masalahnya adalah “Apakah isi LKS Biologi MGMP SMP Kota Semarang yang digunakan siswa kelas VII Semester Gasal 2010 / 2011 sesuai dengan KTSP , tingkat pengaktifan siswa dan jenjang soal-soal latihan pada LKS ?" .

Tujuan yang ingin dicapai dalam penelitian adalah: untuk mengetahui kesesuaian isi LKS Biologi MGMP kota Semarang yang digunakan siswa kelas VII Semester Gasal 2010 / 2011 dengan KTSP, tingkat pengaktifan siswa pada isi LKS Biologi MGMP kota Semarang berdasarkan indeks pengaktifan siswa pada LKS tersebut, persentase jenjang soal-soal latihan LKS Biologi MGMP kota Semarang berdasarkan muatan kognitif, psikomotorik dan afektif.

Adapun manfaat penelitianadalah: 1) Guru dan siswa, agar dapat menggunakan LKS yang lebih mendukung KBM pada tahun pelajaran berikutnya. 2) Penyusun dapat dijadikan masu- 
kan untuk lebih teliti dalam menyusun LKS. 3) Penerbit, dapat dijadikan masukan untuk melakukan revisi LKS sebelum diterbitkan lagi.

Adapun syarat pembuatan LKS menurut Darmojo dan kaligis (1991) meliputi:

1. Syarat didatik, artinya mengikuti asas-asas belajar mengajar yang efektif, yaitu : memperhatikan adanya perbedaan individual, sehingga LKS yang baik adalah yang dapat digunakan untuk siswa yang lamban maupun yang pandai dan kekeliruan yang umum terjadi adalah kelas dianggap satu kesatuan homogeny, tekanan pada proses untuk menentukan konsep-konsep sehingga LKS berfungsi sebagai petunjuk bagi siswa untuk mencari tahu, memiliki stimulus melalui berbagai media dan kegiatan siswa, misalnya menulis, menggambar, berdialog dengan temannya, menggunakan alat, menyentuh benda nyata dan sebagainya.

2. Syarat konstruksi meliputi: penggunaan bahasa disesuaikan dengan tingkat kedewasaan anak, menggunakan kalimat yang jelas, memiliki tata urutan pelajaran yang sesuai dengan tingkat kemampuan anak apabila konsep yang akan dicapai kompleks dapat dipecah menjadi bagian-bagian yang sederhana terlebih dahulu, hindarkan pertanyaan terbuka, yang dianjurkan adalah isian atau jawaban yang didapat dari hasil pengolahan informasi bukan mengambil dari perbendaharaan pengetahuan yang tak terbatas, tidak mengacu pada buku sumber yang di luar kemampuan keterbacaan siswa, misalnya perpustakaan yang jauh dari jangkauan sekolah, menyediakan ruang yang cukup untuk member keleluasaan pada siswa untuk menulis maupun menggambarkan pada LKS, menggunakan kalimat sederhana dan pendek, dapat digunakan untuk siswa yang lamban maupun yang cepat dan memiliki tujuan yang jelas serta manfaat dari pelajaran itu sebagai sumber motivasi.

3. Syarat teknik : Tulisan menggunakan huruf cetak tidak menggunakan huruf latin atau romawi, menggunakan huruf tebal untuk topic, bukan huruf biasa yang diberi garis 
bawah, dalam 1 baris tidak lebih dari 10 kata, perbandingan besarnya huruf dengan besarnya gambar serasi.

Gambar yang baik untuk LKS adalah yang dapat menyampaikan pesan atau isi dari gambar tersebut secara efektif pada pengguna LKS, gambar fotografer berkualitas tinggi belum tentu dapat dijadikan gambar LKS yang efektif, gambar yang bagus adalah yang dapat memperlihatkan kejelasan isi atau pesan dari gambar secara keseluruhan.Menurut penelitian Suhartini (2000), terbukti bahwa LKS dapat memudahkan guru untuk mengontrol siswa dan menyimpulkan materi yang dibahas dan siswa menjadi lebih tertarik untuk menemukan konsep-konsep yang dipelajari secara mandiri.

Dalam penelitian Ahmadi (2008) terbukti bahwa penggunaan LKS sebagai media untuk meningkalam pembelajartkan motivasi belajar siswa dalam pembelajaran PKn di kelas VII SMPN 44 Jakarta lebih efektif.LKS merupakan bimbingan guru Dalam pembelajaran yang disajikan secara tertulis, maka dalam penilaiannya perlu memperhatikan criteria media grafis sebagai media visual. Penyusun LKS ini dilakukan oleh seluruh anggota dari MGMP biologi kota Semarang. Setiap guru memperoleh tugas menyusun tiap pokok bahasan tertentu.

Setelah semuanya terkumpul baru diadakan editing oleh tim editor dan selanjutnya dicetak.Adapun susunan / urutan penyajian LKS ini meliputi:

1) judul bab atau pokok bahasan,

2) standar kompetensi,

3) kompetensi dasar,

4) ringkasan materi yang berupa poin-poin penting dari materi pembelajaran,

5) kegiatan pengamatan atau praktikum,

6) uji kompetensi atau latihan soal.

Menurut UU RI No. 20 tahun 2003 tentang system Pendidikan Nasional dan Peraturan Pemerintah RI No. 19 Tahun 2005 tentang standar nasional pendidikan, mengamanatkan setiap 
satuan pendidikan untuk membuat Kurikulum Tingkat Satuan Pendidikan (KTSP) sebagai pengembang kurikulum yang akan dilaksanakan pada tingkat satuan yang bersangkutan.Pada KTSP ditekankan proses pembelajaran yang diselenggarakan secara interaktif, inspiratif, menyenangkan, menantang, memotivasi peserta didik.Untuk berpartipasi aktif, serta memberikan ruang cukup bagi prakarsa, kreativitas dan kemandirian sesuai dengan bakat, minat dan perkembangan fisik serta psikologi peserta didik (Anonim, 2008). Adapun indeks pengaktifan siswa dapat diperoleh dengan membandingkan pertanyaan (kalimat atau diagram / gambar atau soal) yang mengaktifkan siswa untuk berfikir dengan pertanyaan yang kurang mengaktifkan (Widodo 1993).

Menurut (Samana 1992, diacu dalam Anggraini 2006) prinsip-prinsip pengaktifan siswa meliputi:

1. motivasi, berperan sebagai pendorong agar motif yang positif dapat dibangkitkan / ditingkatkan,

2. konteks, mampu menyelidiki pengetahuan, perasaan, ketrampilan, sikap dan pengetahuan yang telah dimiliki siswa,

3. focus, merupakan pusat analisis pengajaran tidak lepas dari konteks,

4. sosialisasi, melatih siswa untuk dapat bekerja sama dengan temannya,

5. belajar sambil bekerja, untuk menyalurkan dan melatih kemampuan bekerja siswa,

6. individualisasi / perbedaan perorangan, menempatkan siswa sebagai subyek atau pribadi yang khas untuk dirinya, jika perbedaan perorangan siswa dipelajari dan dimanfaatkan secara tepat, maka keberhasilan belajar siswa dapat ditumbuhkembangkan,

7. menemukan, member kesempatan kepada siswa untuk mencari dan menemukan getaran pikiran, perasaan dan hati sehingga siswa dapat mengolah pengalamannya, meneksplorasi keilmuan dan menemukan kebenaran,

8. pemecahkan masalah, mendorong siswa untukmelihat masalah, merumuskannya dan berupaya untuk memecahkan 
sejauh mana kemampuan siswa.

Menurut Widodo (1993) indeks pengaktifan siswa dapat dikategorikan : a) indeks pengaktifan siswa pada LKS Kategori Penilaian dalam Petunjuk Kegiatan, meminta siswa untuk melakukan percobaan dengan membuat rancangan eksperimen secara mandiri, menyajikan data, menarik sesimpulan dan mengkomunikasikan hasil percobaannya, b) indeks pengaktifan siswa pada LKS Kategori Pertanyaan, pertanyaan penggalian yang bertujuan untuk lebih memahamkan pola pikir yang dikuasai siswa, jawaban menuntut siswa menggunakan pengetahuan, dan mengharapkan siswa memecahkan permasalahan, pertanyaan factual yaitu menanyakan apa yang diamati dan hubungan obyek yang satu dengan yang lain, jawaban pertanyaan langsung didapat oleh siswa dari ringkasan materi, pertanyaan informative yaitu menanyakan arti dari istilah, jawaban pertanyaan berupa definisi. LKS merupakan salah satu dari sumber belajar yang digunakan oleh siswa dan guru dalam proses belajar mengajar.

Oleh karena isi dari LKS harus mampu menyajikan materi sesui dengan tuntnan kuikulum.LKS yang baik haruslah dapat meningkatkan kualitas paserta didik sehingga soal-soal latihan tersebut dapat dijadikan sarana untuk mengetahui pemahaman siswa dan dapat meningkatkan kualitas peserta didik.Analisis jenjang soal-soal latihan ini bertujuan untuk mengetahui seberapa besar tuntutan soal-soal latihan dalam menguji kemampuan siswa.

1. jenjang soal ranah kognitif menuruttaksonomi Bloom, dikategorikan menjadi enam yaitu ingatan, pemahaman, aplikasi, analisis, sintesis dan evaluasi, kedua aspek yang pertama disebut jenjang kognitif rendah sedangkan keempat yang lainnya disebut jenjang kognitif tingkat tinggi ( Sudjana 2006).

2. jenjang soal ranah psikomotorik, dikategorikan dalam lima jenjang (Sympson dan Harrow 1969, diacu oleh Sugandi dan Haryanto 2004) yaitu peniru / imitasi ( imitation ), manipulasi (manipulation), ketepatan (precision), artikulasi ( articula- 
tion ) dan pengalamiahan (naturalization),

3. jenjang ranah afektif, dikategorikan dalam lima jenjang (Krathwohl 1964, diacu dalam Sugandi dan Haryanto 2004 ) yaitu jenjang kemampuan menerima, menanggapi, keyakinan, mengorganisasi dan menyatakan.

\section{METODOLOGI PENELITIAN}

Eksplorasi awal dilakukan tanggal 5 Agustus 2010, untuk mendapatkan data LKS yang dilaksanakan dikota Semarang.Adapun populasi dalam penelitian ini adalah LKS Biologi MGMP SMP di kota Semarang tahun pelajaran 2010 / 2011 yang digunakan siswa kelas VII sampai kelas IX. Sampel penelitian berupa LKS Biologi MGMP SMP kelas VII semester ganjil pelajaran 2010 / 2011Variabel yang digunakantahun dalam penelitian meliputi: kesesuaian isi LKS dengan KTSP, Tingkat pengaktifan siswa pada isi LKS berdasarkan indeks pengaktifan siswa paada isi LKS, jenjang soal-soal latihan pada LKS berdasarkan muatan kognitif, psikomotorik dan afektif.

Rancangan penelitian menggunakan metode observasi untuk memperoleh data. Tahapan observasi dibagi menjadi dua, yaitu 1) persiapan:observasi awal dilakukan untuk mendapatkan data LKS yang digunakan siswa dan guru dalam KBM meliputi nama LKS, penerbit, dan pemgarang, alasan penggunaan LKS dan rencana penggunaan lagi. Observasi dilakukan melalui wawancara dengan siswa dan guru SMP di kota Semarang, selanjutnya menyusun instrument dan menganalisis instrument untuk melihat validitasnya, menurut Arikunto (2002) suatu instrument dikatakan valid apabila mampu mengukur atau mengungkap data dari variable yang diteliti secara tepat. Validitas instrument yang akan diungkap berupa validitas isi (Widodo 1993).

Adapun reliabilitas menunjukkan bahwa suatu instrument cukup dapat dipercaya untuk digunakan sebagai alat pengumpul data karena instrument tersebut sudah baik (Arikunto 2002). Dalam penelitian ini reliabilitas instrument dihitung dengan menggunakan harga kesepakatan antar pengamat (K). Adapun 
Rumus untuk menghitung harga K adalah sebagai berikut:

$$
\begin{array}{ll}
K K=\frac{P o-P e}{1-P e} & \text { Rumus 1 } \\
P e=\frac{1}{N^{2}} \sum\left(n_{1+}\right) x\left(n_{+1}\right) & \text { Rumus 2 }
\end{array}
$$

Keterangan;

$\mathrm{K}=$ Koefisien kesepakatan pengamat

$P_{o} \quad=$ Proporsi dari frekuensi kesepakatan

$P_{e} \quad=$ Kemungkinan kesepakatan

$\mathrm{N} \quad=$ Jumlahkeseluruhan jari-jari yang menunjukkan munculnya gejala yang teramati

$\sum\left(n_{1+}\right)=$ jumlah jari-jari ke -1 untuk pengamat pertama

$\sum\left(n_{+1}\right)=$ jumlah jari-jari ke -1 untuk pengamat kedua

Pelaksanaan: kesesuaian materi dengan KTSP, tingkat pengaktifan siswa berdasarkan indeks pengaktifan siswa pada isi LKS, Persentase jenjang soal-soal latihan pada LKS berdasarkan muatan kognitif menurut taksonomi Bloom, maupun muatan psikomotor dan afeektf. Metode pengumpulan data yang digunakan dalam penelitian ini adalah metode non tes, yaitu dengan pengisian lembar observasi yang kemudian dianalisis. Adapun analisis dalam penelitian ini dilakukan secara deskriptif, sedangkan untuk menentukan status isi LKS dilakukan kualitatif sehingga analis data yangdigunakan adalah teknik deskriptif kualitatif. Analisis data dilakukan secara deskriptif, sedangkan untuk menentukan status isi LKS dilakukan secara kuantitatif sehingga analisis data yang digunakan adalah teknik deskriptif kualitatif.

\section{(1) analisis data untuk kesesuaian isi LKS dengan KTSP}

adalah dengan mencocokkan isi LKS dengan indicator yang sesuai dengan KTSP. Skor 1 diberikan jika isi LKS dapat memenehi indicator KTSP, skor 0 diberikan jika isi LKS tidak dapat memenehi indicator KTSP. Menurut (Ali 1985, diacu 
dalam anggraini 2006) sebelum data dianalisis secara kualitatif, terlebih dahulu dianalisis dengan teknik Deskriptif Persentase (DP) dengan menggunakan rumus sebagai berikut:

$$
D P=\frac{\sum \text { Indikator yang ada dalam LKS }}{\sum \text { Indikator yang ada dalam kurikulum }} \quad \mathrm{x} 100 \% \quad \text { (Rumus 3) }
$$

Menurut (Ali 1985, diacu dalam anggraini 2006) bahwa persentase yang diperoleh melalui perhitungan DP, dapat ditafsirkan dengan kategori yang bersifat kualitatif (tabel1) kategori kesesuaian materi dengan kurikulum berdasarkan harga deskriptif persentase (DP).

\begin{tabular}{|c|c|}
\hline Persentase & Katagori \\
\hline $66,67-100$ & Tinggi \\
\hline $33,34-66,66$ & Sedang \\
\hline $0,00-33,33$ & Rendah \\
\hline
\end{tabular}

\section{2). Analisis data untuk indeks pengaktifan siswa pada LKS} menurut Widodo (1993) dapat dihitung dengan rumus sebagai berikut:

$$
I P=\frac{\text { Pernyataan yang mengaktifkan }}{\text { pernyataan yang kurang mengaktifkan }} \quad 100 \% \text { (Rumus 4) }
$$

Analisis data untuk indeks pengaktifan siswa pada isi LKS penelitian ini adalah penilaian pada kalimat, penilaian diagram atau gambar dan penilaian soal latihan atau uji kompetensi pada akhir bab.

a) Penilaian pada petunjuk kegiatan, rumus yang digunakan:

$$
\mathrm{IP}=\frac{(a)+(b)+(c)+(d)}{(e)+(f)+(g)+(h)} \quad \mathrm{x} 100 \% \quad \text { (Rumus 5) }
$$

Keterangan :

$\mathrm{a}=$ petunjuk kegiatan yang meminta siswa untuk melakukan percobaan dengan membuat rancangn eksperimen secara mandiri, menyajikan data, menarik kesimpulan dan 
mengkomuni kasikan hasil percobaannya.

$\mathrm{b}=$ petunjuk kegiatan yang meminta siswa untuk melakukan percobaan dengan merancang eksperimen secara mandiri, menyajikan data, menarik kesimpulan.

$\mathrm{c}=$ petunjuk kegiatan yang meminta siswa untuk melakukan percobaan dengan membuat rancangan eksperimen yang sudah ditentukan, menyajikan data, menarik kesimpulan dan mengkomunikasikan hasil percobaannya.

$\mathrm{d}=$ petunjuk kegiatan yang meminta siswa untuk melakukan percobaan dengan rancangan eksperimen yang sudah ditentukan dan menyajikan data dan menarik kesimpulan

$\mathrm{e}=$ petunjuk kegiatan yang meminta siswa untuk melakukan percobaan dengan rancangan eksperimen yang sudah ditentukan dan menyajikan data hasil percobaan

$\mathrm{f}=$ petunjuk kegiatan yang hanya meminta siswa untuk melakukan percobaan dengan racangan eksperimen yang sudah ditentukan

$\mathrm{g}=$ petunjuk kegiatan yang tidak mengarah siswa untuk melakukan kegiatan percobaan, hanya mengajukan suatu data hasil pengamatan orang lain

$\mathrm{h}=$ petunjuk kegiatan yang hanya mengarahkan siswa untuk menggali informasi dalam teks.

$a, b, c$ dam d merupakan skor dari frekuensi kemunculan kategori petunjuk kegiatan yang mengaktifkan siswa, e,f,g dan $\mathrm{h}$ merupakan skor dari frekuensi kemunculan kategori petunjuk kegiatan yang tidak atau kurang mengaktifkan siswa.

b) Penilaian pada gambar, rumus yang digunakan:

$$
\text { Indeks pengaktifan }=\frac{(a)}{(b)} \times 100 \% \quad \text { (Rumus 6) }
$$

Keterangan:
a = skor dari frekuensi kemunculan kategori gambar yang mengaktifkan siswa
$\mathrm{b}=$ skor dari frekuensi kemunculan kategori gambar yang kurang mengaktifkan siswa


Kategori gambar yang mengaktifkan siswa adalah gambar yang mengharapkan siswa menggunakan data atau melakukan kegiatan. Sedangkan gambar atau diagram yang kurang mengaktifkan siswa adalah gambar yang hanya berfungsi sebagai materi pelajaran.

c) Penilaian Soal-soal latihan, rumus yang digunakan :

$$
I P=\frac{(a)+(b)}{(c)+(d)} \times 100 \%
$$

Ketrangan:

$\mathrm{a}=$ pertanyan penggalian, yaitu pertanyan yng bertujuan untuk lebih memahamkan pola pikir yang telah dikuasai siswa, jawaban menurut siswa untuk menggunakan pengetauhuan atau situasi baru.

$\mathrm{b}=$ pertanyan penyelesaian masalah, jawaban pertanyaan mengharapkan siswa untuk memecahkan masalah.

c = pertanyan faktual, yaitu menanyakan apa yang diamati dan hubungan obyek yang satu dengan obyek yang lain, jawaban pertanyaan langsung didapat oleh siswa dari teks atau ringkasan materi.

$\mathrm{d}=$ pertanyaan informatif, yaitu yang menanyakan arti istilah, jawaban pertanyaan berupa definisi.

a dan b merupakan skor dari frekuensi kategori soal-soal yang mengaktifkan siswa, c dan d merupakan skor dari frekuensi kategori soal-soal yang kurang atau tidak mengaktifkan siswa. Menurut Widodo (1993) hasil perhitungan data untuk kalimat, gambar maupun soal-soal latihan kemudian dianalisis berdasarkan kriteria berikut: Tabel 2, kategori pengaktifan siswa berdasarkan harga skor indeks pengaktifan (IP). 


\begin{tabular}{|c|c|}
\hline Skor & kategori \\
\hline 1,50 & Tinggi \\
\hline $0,40-1,50$ & Sedang \\
\hline $0,00-0,40$ & Rendah \\
\hline
\end{tabular}

(3) Analisis data untuk menentukan jenjang kesulitan soalsoal latihan berdasarkan muatan kognitif.

Langkah-langkah yang dilakukan adalah dengan memisahkan pertanyaan berdasarkan kategori yang telah ditetapkan dengan ketentuan: kategori C1 : pengetahuan (knowledge), C2: pemahaman (comprehension), C3: Penerapan (application), C4: analisis (analysis), C5: sintesis (synthesis) dan C6: penilaian (evaluation). Untuk mengetahui persentase masing-masing jenjang soal latihan digunakan rumus sebagai berikut:

$$
D P=\frac{\text { jumlah soal jenjang tertentu }}{\text { jumlah seluruh soal }} \times 100 \% \quad \text { (Rumus 8) }
$$

Jenjang soal latihan dikatakan proporsional apabila memiliki persentase masing-masing jenjang sebagai berikut : $\mathrm{C} 1= \pm$ $12,5 \%, \mathrm{C} 2= \pm 17,5 \%, \mathrm{C} 3= \pm 20 \%, \mathrm{C} 4= \pm 20 \%, \mathrm{C} 5= \pm 17,5 \%, \mathrm{C} 6$ $= \pm 12,5 \%$. (4) Analisis data untuk menentukan jenjang kesulitan soal-soal latihan berdasarkan muatan psikomotorik, langkah yang dilakukan adalah dengan memisahkan pertanyaan berdasarkan kategori yang telah ditetapkan dengan ketentuan : kategori P1: peniruan / imitasi, P2: manipulasi, P3: ketetapan, P4: artikulasi dan P5: pengalamiahan . Untuk mengetahui persentase masing-masing jenjang soal latihan digunakan rumus sebagai berikut:

$$
D P=\frac{\text { jumlah soal jenjang tertentu }}{\text { jumlah seluruh soal }} \times 100 \% \quad \text { (Rumus 8) }
$$

Jenjang soal latihan dikatakan proporsional apabila memiliki persentase masing-masing jenjang sebagai berikut: P1 $= \pm$ $17,5 \%, \mathrm{P} 2= \pm 20 \%, \mathrm{P} 3= \pm 25 \%, \mathrm{P} 4= \pm 20 \%, \mathrm{P} 5= \pm 17,5 \%$, 
Analisis data untuk menentukan jenjang kesulitan soal-soal latihan berdasarkan muatan afektif, langkah yang dilakukan adalah dengan memisahkan pertanyaan berdasarkan kategori yang telah ditetapkan dengan ketentuan : kategori A1: kemampuan menerima, A2: kemampuan menang gapi, A3: kemampuan keyakinan, A4: kemampuan mengorganisasi A5: kemampuan menyatakan. Untuk mengetahui persentase masing-masing jenjang soal latihan digunakan rumus sebagai berikut:

$$
\left.D P=\frac{\text { jumlah soal jenjang tertentu }}{\text { jumlah seluruh soal }} \times 100 \% \quad \text { (Rumus } 8\right)
$$

Jenjang soal latihan dikatakan proporsional apabila memiliki persentase masing-masing jenjang sebagai berikut: $\mathrm{A} 1= \pm$ $17,5 \%, \mathrm{~A} 2= \pm 20 \%, \mathrm{~A} 3= \pm 25 \%, \mathrm{~A} 4= \pm 20 \%, \mathrm{~A} 5= \pm 17,5 \%$.

\section{HASIL DAN PEMBAHASAN}

LKS merupakan salah satu penunjang saran pembelajaran yang digunakan sebagai panduan dalam berlatih mengerjakan soal-soal, juga sebagai alternatif pemberian tugas oleh guru. Hasil penelitian mengkaji kesesuaian LKS dengan KTSP masuk kategori sedang. Hal ini disebabkan perolehan skor 62,5\%. Menurut (Ali 1985 diacu Anggraini 2006) persentase antara 33,34 - 66,66 dapat dikategorikan sedang, sehingga LKS tersebut dapat dikatakan cukup memenuhi tuntutan KTSP.

Materi dalam LKS MGMP Biologi Kota Semarang telah memenuhi 20 indikator dari 32 indikator yang tercantun dalam KTSP menurut (Dhari 1998 diacu dalam Rejeki 2005) bahwa LKS memiliki manfaat salah satunya membantu siswa mengembangkan konsep. Meskipun LKS karya MGMP persentasenya dikategorikan sedang, tetapi banyak hal yang menjadi tuntutan kurikulum yang belum dipenuhi oleh LKS tersebut dikarenakan sumber yang digunakan sebagai acuan oleh guru dalam menyusun LKS belum sesuai dengan KTSP. Jadi, perlu diperhatikan lagi dari penyusun apabila akan melakukan perbaikan terhadap isi LKS tersebut sebelum diterbitkan lagi. 
Deskripsi data tingkat pengaktifan siswa pada LKS dibagi menjadi 3 kategori, yaitu tingkat pengangtifan siswa pada petunjuk kegiatan, gambar dan soal-soal latihan. Selain memuat materi pembelajaran LKS juga memuat petunjuk kegiatan yang bertujuan untuk memudahkan siswa memahami materi yang dipelajarinya. indeks pengaktifan siswa pada petunjuk kegiatan sebesar 0,03 yang tergolong rendah, karena berada pada rentang 0,00-0,40. Adapun deskripsi data tingkat pengaktifan siswa berupa gambar sebesar 1,37 tergolong sedang karena berada pada rentang $0,40-1,50$, maka dapat dikatakan sudah memenuhi kriteria prinsip-prinsip pengaktifan siswa. Hal ini sesuai dengan Darmojo dan Kaligis (1991) bahwa syarat LKS yang baik menggunakan lebih banyak ilustrasi dari pada kata-kata, Pada umumnya LKS banyak memuat soal-soal latihan, deskripsi data tingkat pengatifan siswa pada soal-soal latihan 1,23 kategori sedang karena berada pada rentang 0,40 - 1,50.

Soal-soal dalam LKS tersebut sudah dapat mengaktifkan siswa, namun perlu adanya perhatian pada soal pemecahan masalah, sehingga menjadi pekerjaan rumah bagi penyusun untuk menyempurnakan LKS tersebut sebelun diterbitkan kembali. Adapun jenjang Soal latihan pada LKS di bagi menjadi tiga ranah, yaitu rnah kognitif, ranah psikomotorik dan ranah afektif . Setiap ranah jenjang soal mempunyai kriteria- kriteria sendiri. Menurut taksonomi Bloom jenjang Soal ranah kognitif dikategorikan menjadi enam kategori, yaitu ingatan / pengetahuan (C1), pemahaman (C2) aplikasi (C3), analisis (C4), sintesis (C5) dan evaluasi (C6). Jenjang soal kognitif dikatakan proporsional apabila memiliki persentase masing-masing jenjang sebagai berikut: $\mathrm{C} 1= \pm 12,5 \%, \mathrm{C} 2= \pm 17,5 \%, \mathrm{C} 3= \pm 20 \%, \mathrm{C} 4= \pm$ $20 \%, C 5= \pm 17,5 \%, C 6= \pm 12,5 \%$. Jika mengacu pada persentase tersebut, jumlah soal jenjang C3 dan C4 seharusnya lebih banyak dibandingkan dengan jumlah jenjang soal yang lain.

Berdasarkan data yang diperoleh LKS MGMP persentase C1 jauh lebih besar dibandingkan jenjang kesulitan soal-soal lainnya yaitu 40,8\%, hal ini menunjukkan bahwa LKS muatan kognitif kurang proporsional, karena jenjang soal lebih domina- 
si jenjangsoal-soal yang lain. Persentase jenjang soal C2 sebesar $31,38 \%$. Hal ini akan menyebabkan siswa kurang mendapat kesasempatan untuk menguji kemampuan berlatih menyelesaikan soal-soal pemahaman, sehingga siswa kurang dilatih untuk mencoba lebih memahami suatu konsep.

Persentase jenjang soal C3 sebesar 6,36\% berarti LKS ini memiliki proporsi jenjang soal aplikasi rendah, dan seharusnya jenjang soal aplikasi harus lebih banyak proporsinya dibanding jenjangsoal-soal yang lain. Persentase C4 sebesar 8,63\% jenjang soal pada LKS dikatakan belum porposional karena seharusnya jenjang soal C4 mempunyai proporsi lebih banyak seperti proporsi jenjang soal C3. Persentase jenjang soal C5 sebesar 1,28\%. Hal ini jauh dari proporsinal untuk ukuran soal C5, sedangkan persentase jenjang soal C6 sebesar 1,36\% Persentase jenjang soal C6 tidak proporsinal karena sulitnya mengaplikasikan soal evaluasi ini.

Jenjang soal ranah psikomotorik dikategorikan dalam lima jenjang yaitu imitasi (P1), manipulasi (P2), ketepatan (P3), artikulasi (P4) dan pengalamiahan (P5). Jenjang soal psikomotorik dikatakan proporsional apabila memiliki persentase masing-masing jenjang sebagai berikut: $\mathrm{P} 1= \pm 17,5 \%, \mathrm{P} 2= \pm 20 \%, \mathrm{P} 3= \pm$ $25 \%, \mathrm{P} 4= \pm 20 \%, \mathrm{P} 5= \pm 17,5 \%$. Berdasarkan deskripsi data jenjang kesulitan soal-soal latihan berdasarkan muatan psikomotorik tidak proporsional atau kurang merata karena soal lebih banyak masuk kategori P2 (0,43\%) danP3 (1,3\%) sedangkan jenjang soal yang lain tidak ditemukan.

Penilaian psikomotorik merupakan penilaian terhadap ketrampilan siswa yang lebih tepatnya jika dilakukan secara langsung saat siswa melakukan kegiatan. Namun, dalam kenyataanya guru sering mengalami kesulitan untuk memberikan penilaian psikomotorik pada siswa. Jenjang-jenjang soal dalam ranah afektif dikategorikan dalam empat jenjang, yaitu kemampuan menerima (A1), menanggapi (A2), keyakinan (A3) dan menanyakan (A4). Deskripsi data pengaktifan siswa kategori soal-soal latihan afektif pada LKS tidak ditemukan, karena sulit mengaplikasikan muatan afektif ke dalam bentuk soal. 
Penilaian afektif merupakan penilaian terhadap sikap atau prilaku siswa, sehingga lebih tepat dilakukan secara langsung dengan melihat sikap atau prilaku siswa saat pembelajaran berlangsung. Namun sebaiknya penerapan soal afektif ini perlu diterapkan seperti jenjang soal ranah psikomotorik. Selanjutnya mengenai kualitas LKS yang telah dianalisis secara umum memiliki kualitas yang cukup baik walaupun masih ada beberapa kekurangan yang perlu mendapat perhatian lagi dari pihak penyusun untuk diperbaiki mengingat banyak sekolah-sekolah di Kota Semarang yang menggunakan LKS tersebut.

Adapun kelebihan dari LKS ini adalah telah memenuhi KTSP, tingkat kesesuaiannya tinggi, sedangkan kelemahan LKS terletak pada soal-soal latihannya yang kurang proporsional untuk masing-masing jenjang. Bahkan untuk ranah afektif tidak ditemukan. Untuk tngkat pengaktifan siswa dalam LKS tersebut sudah cukup baik. Menurut (Darmojo dan Kaligis, 1991) persyaratan LKS yang baik meliputi tiga aspek, yaitu syarat didaktif, konstruktif dan teknik. Secara umum LKS ini telah memenuhi ketiga syarat tersebut, walaupun ada beberapa hal yang perlu diperbaiki sebagaimana telah diuraikan di atas. 


\section{PENUTUP}

\section{Simpulan:}

1. LKS Biologi karya MGMP Kota Semarang tahun 2010/ 2011 kategori sedang dengan skor 6,25\% untuk kesesuaian materi dengan KTSP

2. LKS ini belum sesuai dengan kriteria pengaktifan siswa pada petunjuk kegiatan dengan indeks pengaktifan 0,03 kategori rendah, pengaktifan siswa berupa gambar sebesar 1,37 tergolong sedang dan pengaktifan siswa pada soal latihan sebesar 1,23 kategori sedang.

3. Jenjang soal-soal latihan untuk ranah kognitif belum proposional karena soal C1 (40,8\%) dan C2 (35\%) lebih mendominasi disbanding proporsi soalyang lain. Soal psikomotorik juga belum proposional yang didominasi soal P3 (1,3\% ) dan hanya ditemukan soal P2 dan P3. Bahkan dlam LKS ini tidak ditemukan soal ranah afektif

\section{Saran}

1. Bagi guru agar lebih teliti dalam memilih LKS yang akan dijaikan panduan dalam kegiatan belajar mengajar.

2. Bagi penyusun LKS hendaklahlebih memprhatikan kaidahkaidah dan prinsip-prinsip penulisan LKS terutama pada tingkat pengaktifant siswa dan porposi jenjang-jenjang soal latihan.

3. Bagi penerbit LKS hendaknya perlu melakukan revisi untuk LKS terbitan tahub pelajaran yang akan dating.

4. LKS hanya sebagai pendamping bukan sumber utama yang digunakan dalam pembelajaran. 


\section{DAFTAR PUSTAKA}

Ahmadi. 2008. Media Pembelajaran. Jakarta. On ine at http://www. Curriki. Org/xwiki/bin/download/coll sulasmika/ Artikelmediapembelajaran/artikelpembelajaran.com,(accessed 15 Juni 2008)

Anggraini Y. 2006. Analisis LKS Biologi SMP Kelas VII Semester I yang digunakan SMP Negeri di Kota Semarang Tahun Pembelajaran 2005/2006. (Skripsi). Semarang: Universitas Negeri Semarang

Anonim. 2006. Standar Kompetensi Dan Kompetensi Dasar Biologi SMP/MTs. Jakarta: Debdikbud.

Arikunto. S. 2002.Prosedur Penelitian . Jakarta: PT Rineka Cipta.

Darmodjo D \& Kaligis JRE. 1991.PendidikanA IPA II. Jakarta: Dirjen Dikti Depdikbud.

Saptono S. 2003. Strategi Belajar Mengajar. Semarang: Universitas Negeri Semarang

Sudjana N. 2006. Penilaian Hasil Proses Belajar Mengajar. Bandung: PT Remaja Rosdakara

Sugandi A \& Haryanto. 2004. Teori Pembelajaran. Semarang: Universitas Negeri Semarang

Zakiah.2008.http://metodepenelitian.multiply.com/jurnal/ item/6(accessed 29 mei 2008) 